\title{
Short Communication: \\ Land cover changes from 2005 to 2015 in Mantangai area of Dayak Ngaju, Central Kalimantan, Indonesia
}

\author{
BAMBANG HERO SAHARJO ${ }^{1, v}$, EREKSO HADIWIJOYO ${ }^{2, \bullet \vee}$ \\ ${ }^{1}$ Faculty of Forestry, Faculty of Forestry, Institut Pertanian Bogor. Jl. Ulin, Dramaga Campus, Bogor 16680, West Java, Indonesia. \\ Tel.: +62-251-8621267, Fax.: +62-251-8621677, `email: bhherosaharjo@ gmail.com \\ ${ }^{2}$ Faculty of Agriculture, Universitas Brawijaya. Jl. Veteran, Malang 65145, East Java, Indonesia. Tel.: +62-341-565845, •^email: e.hadiwijoyo@gmail.com
}

Manuscript received: 10 June 2019. Revision accepted: 22 August 2019.

\begin{abstract}
Saharjo BH, Hadiwijoyo E. 2019. Short Communication: Land cover changes from 2005 to 2015 in Mantangai area of Dayak Ngaju, Central Kalimantan, Indonesia. Biodiversitas 20: 2596-2602. Forest and land fires in Indonesia are well recognized, directly or indirectly, as the main contributors to deforestation and greenhouse gas emission related to the global climate change. Usually, local peoples are blamed for those fires especially when negative impact occurred. Fortunately, not all of the local peoples do the same thing as it is shown by Dayak Ngaju in Block A of ex-Mega Rice Project (Ex-MRP) Project area located in Mantangai sub-district Kapuas district, Central Kalimantan Province, Indonesia, where this research was conducted. The objective of this study was to know land the cover changes related to the use of fire for land preparation, and how the Dayak Ngaju people implement their knowledge and experience in the field. This objective was achieved by analyzing satellite images of Landsat 7 and 8 for a period of time starting from 2005 to 2015. Results of the research showed that the local people started clearing the land with fire at the end of September (dry season) or early October (the rainy season) yearly, as it could be seen from the changes of the land cover from secondary swamp forest into swamp shrub and from secondary swamp forest into fields. Meanwhile, at the protected area where peat was dominant, land cover change occurred due to land rights conflicts, and not to the use of fire for land preparation using fire by Dayak Ngaju communities, because they found that the results were not good and the planted rice would die three months after planting..
\end{abstract}

Keywords: Community, cover change, Dayak Ngaju, fire, peat

\section{INTRODUCTION}

Large forest fires occurred in 1982/1983, then in 1997/1998, 2002, 2006, 200, 2012 and 2015, most of which occurred in the area of peat (Saharjo et al. 2017). The large fires are usually worsened by El-Nino which make forests and land more flammable. Forest fires lead to a land cover change because of the loss of the vegetation. Land cover changes are generally caused by the activities of people who just think about current needs but never think about the future and learn from the past (Haque and Basak 2017). One of these activities is the used fire for land preparation.

Land preparation using fire has long been done by the local peoples to prepare the land before planting in Indonesia because this method is easy, cheap and quick, in accordance with the targets and adds fertilizer directly to the field (Goldammer 1993, Sahario 2016). The farmers practicing shifting cultivation used fire for land preparation (Goldammer 1993) without any environmental problems like now. Shifting agriculture systems in their early practice and extends were largely determined by low human population pressure on the forest resources. They provided a sustainable base of subsistence for indigenous forest inhabitants, and their patches had little effects on overall forest ecosystem stability (Nye and Greenland 1960). By burning they will get free minerals from the ash that is rich of organic-carbon, phosphorus, magnesium, potassium, and sodium. The nutritional value of soil increases after burning, but only temporarily, because when the rain comes, the nutrients will be leached (Saharjo 1995). The ways of using fire for land preparation are different among the local peoples, which depend on the land characteristics and experience they learn from their ancestors. There are several techniques usually used by the local peoples such as ring firing, pile burning, backfiring, and combination back of firing and firing ring.

The local peoples are usually blamed for forest fires especially when negative impacts occur. Fortunately, not all local peoples do negative things. For example Dayak Ngaju communities in Mantangai, Central Kalimantan conduct control burning in their own land and do not make any disturbances or move to other lands even though the lands are very close and accessible. Controlled burning is one way of the land preparation using fire done by the communities (Saharjo and Munoz 2005). Controlled Burning is a useful method for land management and has a low impact if the technique is applied before and during burning, but it could have very damaging impact if it is done without knowledge (Harper et al. 2017, Saharjo and Munoz 2005). Local wisdom of Dayak Ngaju communities in land preparation is one example of how traditional system called "handles" is implemented (Hadiwijoyo et al. 2017). Those communities have their own way to determine when it should be implemented by recognizing 
the specific natural signs. So, they can make a plan for the land preparation especially for slashing, cutting, drying, burning and planting activities.

In order to know how the local peoples implement their knowledge in using fire for the land preparation in the field and how they deal with the land cover change, remote sensing and geographic information systems (GIS) data can be used. Remote sensing and GIS are technologies that are able to analyze in detail, at a short time, at low cost, and accurately without having to go to the field (Lillesand and Kiefer 2000; Rawat and Kumar 2015; Esmaila et al. 2016). Schroeder et al. (2016) suggest that Landsat 8 is suitable for detecting fire events temporally. GIS is able to detect and evaluate the causes and consequences of land cover changes due to logging and fires (Koshurnikova et al. 2015; Sylla 2012). One cause of land cover changes is land preparation using fire conducted by indigenous communities, such as Dayak Ngaju community in Mantangai Kapuas, Central Kalimantan Province.

This study was conducted to analyze the land cover changes in Mantangai Kapuas, Central Kalimantan Province, Indonesia using remote sensing and geographic information systems (GIS) data, and to see the implementation of local wisdom of the Dayak Ngaju in relation to land cover change.

\section{MATERIALS AND METHODS}

\section{Study site}

The research was conducted from September 2014 until July 2015 in Block A of ex-Mega Rice Project (Ex-MRP) area in Mantangai Sub-district, Kapuas District, Central Kalimantan Province, Indonesia. The site was dominated by grasses, shrubs, and trees. The species of grasses and shrubs found were pawah, sengkuwuk, lampasau, karamunting (Melastoma malabatricum), kalakai (Stenochalaena palustris) (ferns), arbisia, and gerunggang. The species of trees found were tumih (Combretocarpus rotundatus), Macaranga (Macaranga sp.), belangiran (Shorea belangeran), meranti (Shorea sp.), laban (Vitex pubescens) and galam (Melaleuca leucadendron).

\section{Equipment and materials}

Tools used in this study were stationery, voice recorder, camera, GPS, and a computer equipped with software ArcGis 10.1, ENVI, ERDAS, google earth pro, MS Excel for processing graphics and tables. The material used was a map of the area, spatial data about peat depth, data, satellite images Landsat 7 and 8 for a period of time from 2005 to 2015 (when data in Landsat 8 were not available), the land cover data (http://earthexplorer.usgs.gov/ and webgis.dephut.go.id/).

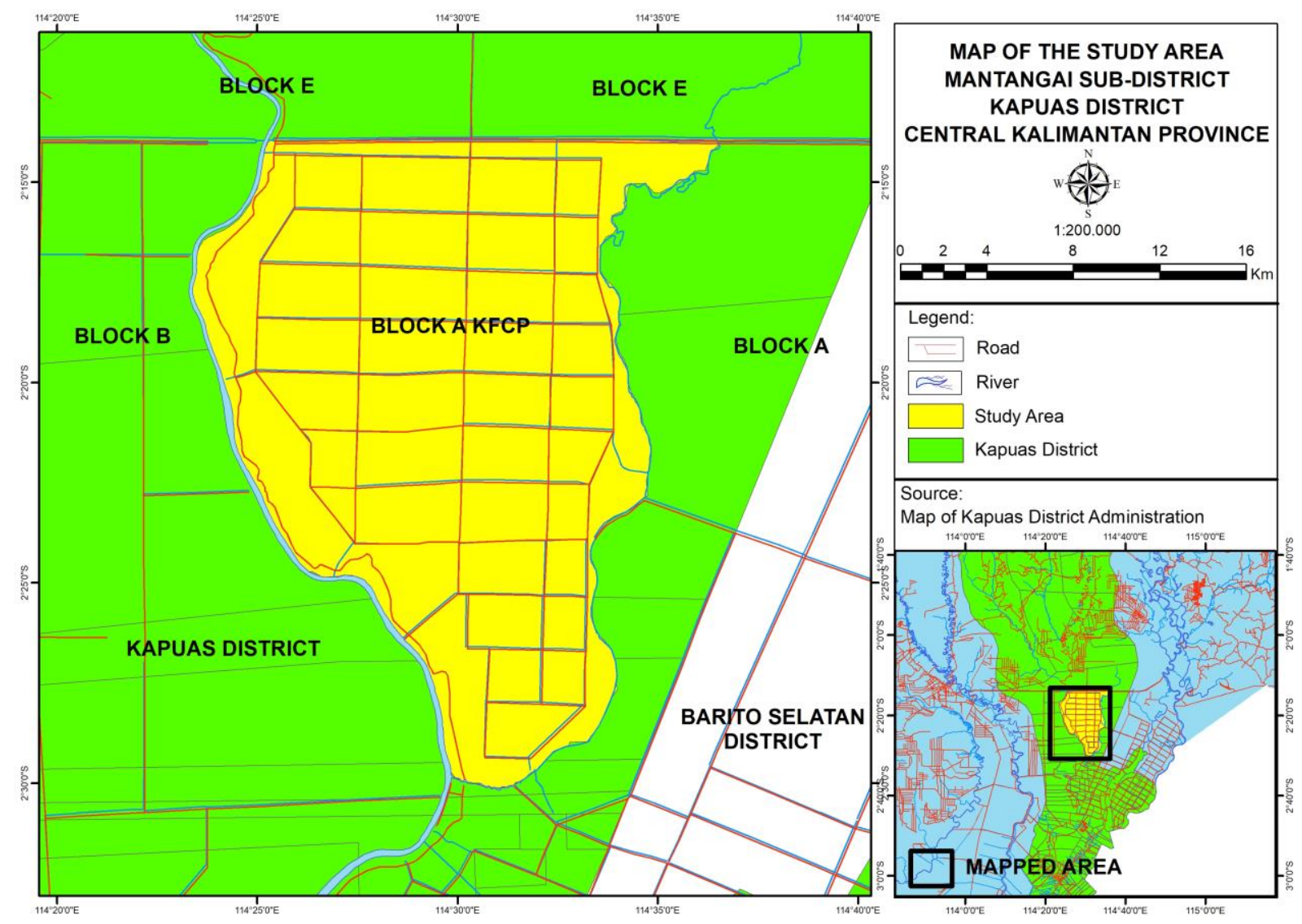

Figure 1. Research area in Block A of ex-Mega Rice Project in Mantangai Sub-district, Kapuas District, Central Kalimantan Province, Indonesia 


\section{Data analyses}

Landsat imagery processing is starting from download from the source (earthexplorer.usgs.gov), Landsat 7 images for the year 2005-2015 and Landsat 8 images for the year 2013-2015. Then it followed by Eraser striping using ERDAS. Calibration and correction using ENVI that included: (i) Radiometric calibration: digital number (DN) OLI Correction to TOA reflectance and DN OLI to TOA radiance; (ii) Correction radiometric: sun angle correction, dark pixel correction, and cloud correction; (iii) Geometric correction. Followed with image cutting, pan sharping and finally get image classification where Landsat 8 classification using ENVI and Landsat 7 classification from hue/color, texture, pattern, shape, shade, size, associations, sites. Finally, from image classification, cover crop area declared (Figure 2).

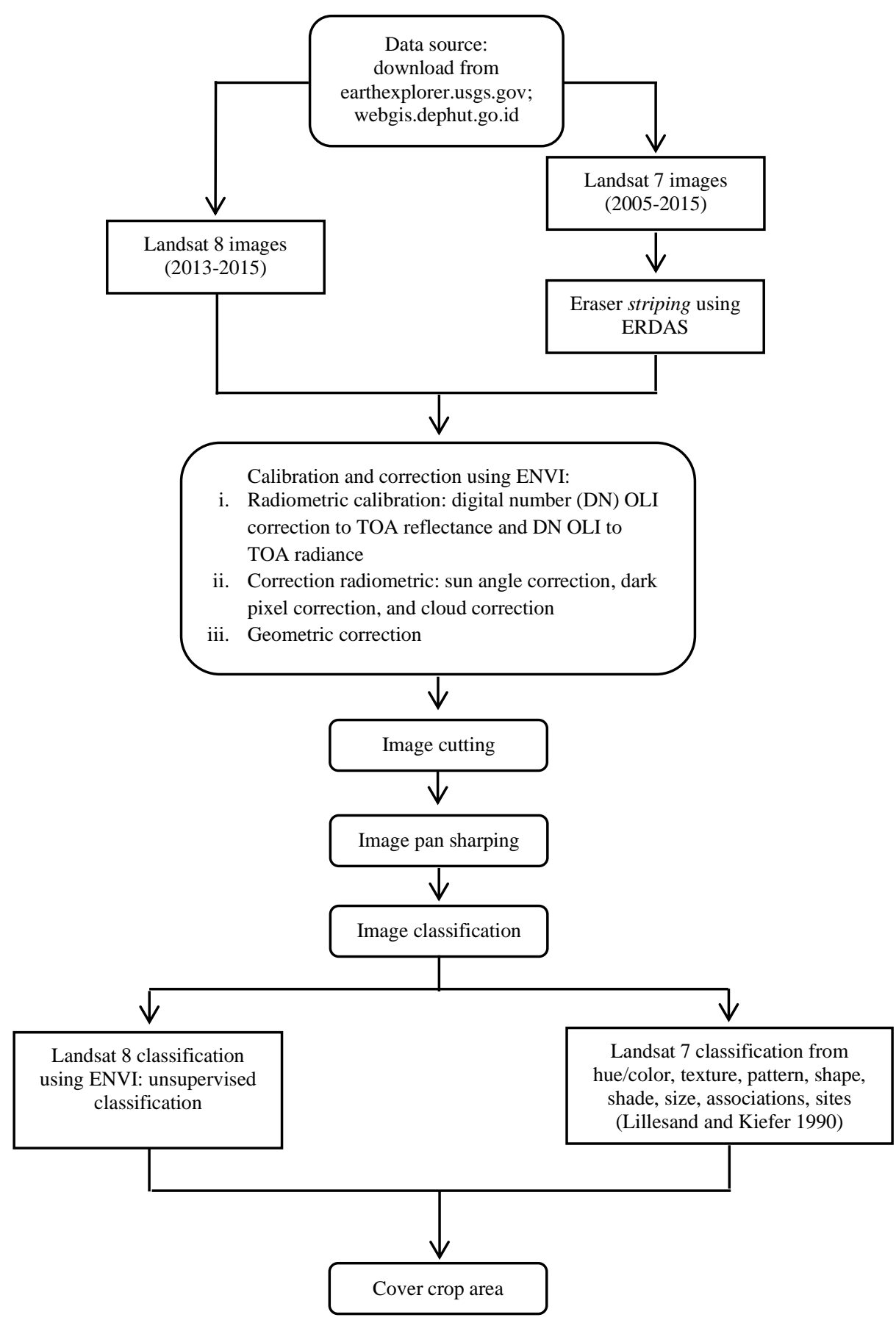

Figure 2. Landsat imagery processing 


\section{RESULTS AND DISCUSSION}

\section{Land cover}

The land cover types in block A of ex-MRP, based on the interpretation of Landsat 7 satellite imagery and Landsat 8, were secondary swamp forest (SSF), swamp shrub (SS), and open land (OL), while based on data from webgis.dephut.go.id/. for 1990, 1996, 2000 and 2003 they were secondary swamp forest (SSF), swamp shrub (SW), and the water body.

\section{Land cover change}

Land cover changes from 1990, 1996, 2000 and 2003 can be seen in Figure 3. Land cover changes in 1990, 1996, 2000 and 2003 were mostly from secondary swamp forest (SWF) into swamp shrub (SS), while in the year 2003 secondary swamp forest (SWF) turned into a water body, and swamp shrub (SS) turned into water body due to the loss of vegetation, then it became open finally. Land cover changes monthly from 2005 to 2015 in the area of the study are presented in Table 1. Unfortunately, monthly land cover data could not be acquired in full for the study area because it was covered with clouds that affect the interpretation of the images.
Table 1 shows that the land cover types in Mantangai Kapuas, Central Kalimantan Province were swamp shrub, secondary swamp forest, and open land. The most extensive swamp shrub changes occurred in June, July, and August each year except in July 2015. Figure 3 shows that land cover changed from 1990 to the following years 1996, 2000 , and 2003, namely from secondary swamp forest into shrubs and from shrubs into water body. Table 1 shows that the area of land cover changes occurred in late September, indicating that the communities started clearing the land with fire at the end of September (dry season) or early October (the rainy season). Figure 4 shows that land cover changes in 2005 and 2015 occurred mostly in swamp shrub (SS).

Land cover changes based on the analysis of Landsat 7 and Landsat 8 were un-supervised, and digitization was done on the screen (Figure 5). Figure 5 shows that the landcover changes in the area of Block A of ex-MRP occurred from July 2005 (A) to August 2005 (B). In 2015 land cover changed from August 2015 (C) to October 2015 (D). The land cover change image could be seen from the changes of the colors among images.

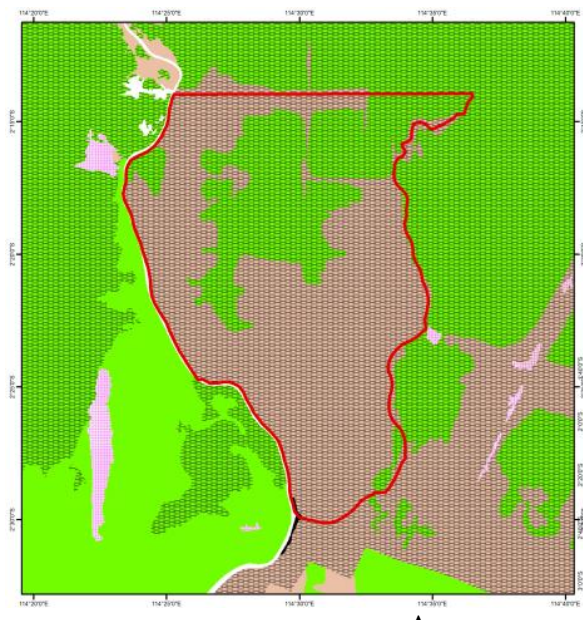

A

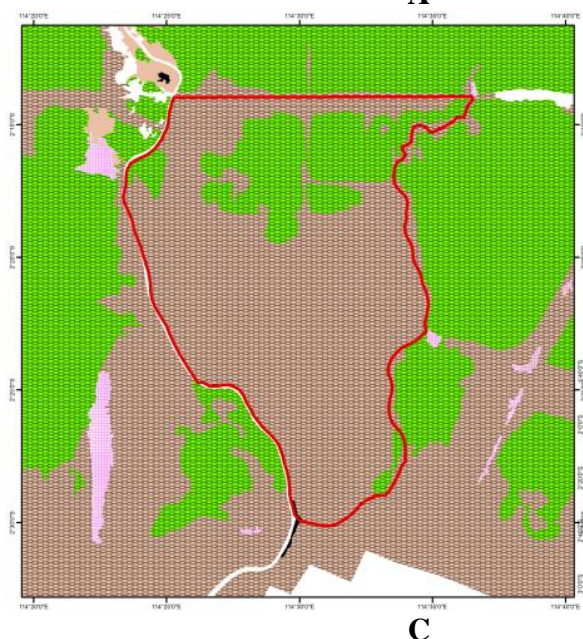

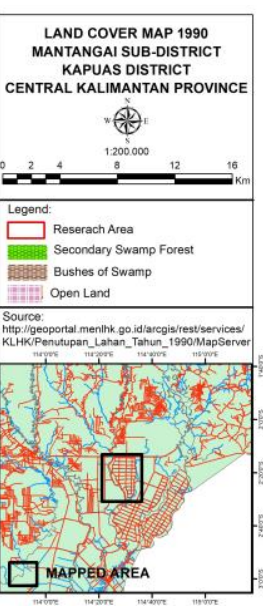

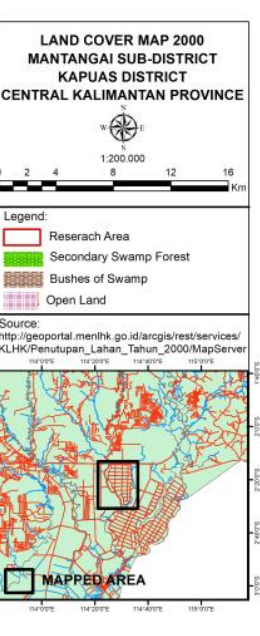

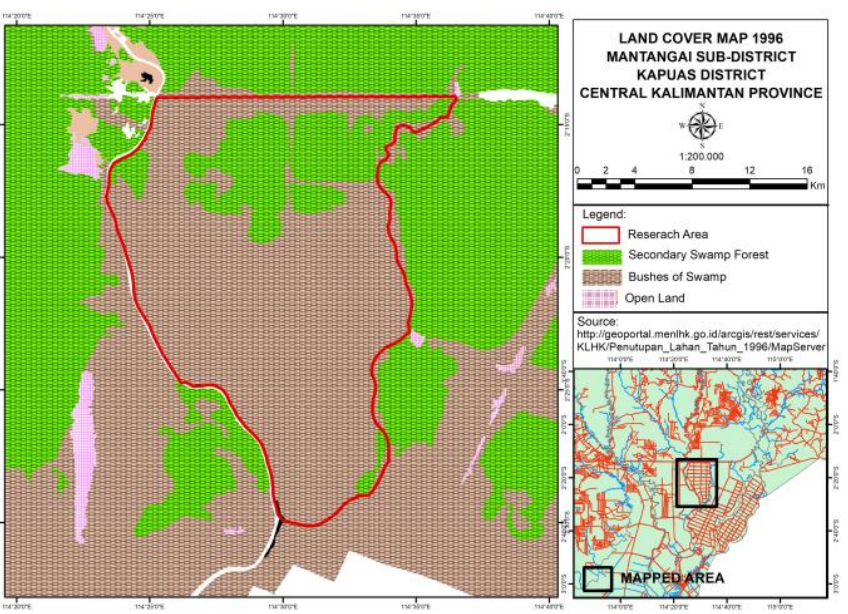

B
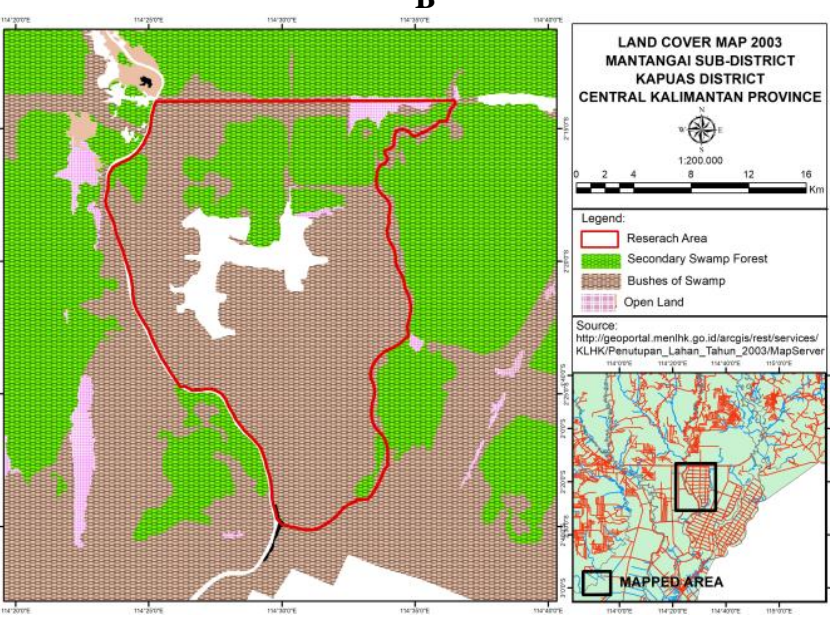

Figure 3. Land cover maps 1990 (A), 1996 (B), 2000 (C), and 2003 (D). Source: webgis.dephut.go.id/ 
Table 1. Monthly land cover expansion in the year 2005-2015in Block A Ex-Mega Rice Project

\begin{tabular}{|c|c|c|c|c|c|c|c|c|c|c|c|c|c|}
\hline \multirow{2}{*}{ Year } & \multirow{2}{*}{$\begin{array}{l}\text { Land cover } \\
\text { type }\end{array}$} & \multicolumn{12}{|c|}{ Monthly land cover expansion (\%) } \\
\hline & & Jan & Feb & Mar & Apr & Mei & Jun & Jul & Agus & Sept & Okt & Nov & Des \\
\hline \multirow[t]{4}{*}{2005} & $\mathrm{C}$ & & & & & & 1.53 & - & 0.63 & & & & - \\
\hline & SSF & NA & NA & NA & NA & NA & 17.77 & 18.06 & 18.17 & NA & NA & NA & 17.51 \\
\hline & SS & & & & & & 66.63 & 67.18 & 64.93 & & & & 55.25 \\
\hline & OL & & & & & & 14.06 & 14.76 & 16.27 & & & & 27.54 \\
\hline \multirow[t]{4}{*}{2006} & $\mathrm{C}$ & & & & & & & 0.79 & - & & & & \\
\hline & SSF & NA & NA & NA & NA & NA & NA & 18.36 & 18.76 & NA & NA & NA & NA \\
\hline & SS & & & & & & & 69.44 & 66.16 & & & & \\
\hline & OL & & & & & & & 11.41 & 15.07 & & & & \\
\hline \multirow[t]{4}{*}{2007} & $\mathrm{C}$ & & & & & & & - & - & & & & \\
\hline & SSF & NA & NA & NA & NA & NA & NA & 11.11 & 11.46 & NA & NA & NA & NA \\
\hline & SS & & & & & & & 77.66 & 73.57 & & & & \\
\hline & OL & & & & & & & 11.23 & 14.97 & & & & \\
\hline \multirow{4}{*}{2009} & $\mathrm{C}$ & & & & & & & 5.31 & & & & & \\
\hline & SSF & N/A & N/A & N/A & N/A & N/A & N/A & 11.00 & N/A & N/A & N/A & N/A & N/A \\
\hline & SS & & & & & & & 49.11 & & & & & \\
\hline & OL & & & & & & & 34.59 & & & & & \\
\hline \multirow[t]{4}{*}{2012} & $\mathrm{C}$ & & 12.27 & & & & & & - & & & & \\
\hline & SSF & N/A & 23.20 & N/A & N/A & N/A & N/A & N/A & 11.47 & N/A & N/A & N/A & N/A \\
\hline & SS & & 32.18 & & & & & & 51.23 & & & & \\
\hline & OL & & 32.35 & & & & & & 37.30 & & & & \\
\hline \multirow[t]{4}{*}{2013} & $\mathrm{C}$ & & & & & & & 2.45 & & & & & 3.20 \\
\hline & SSF & N/A & N/A & N/A & N/A & N/A & N/A & 21.66 & N/A & N/A & N/A & N/A & 19.58 \\
\hline & SS & & & & & & & 64.23 & & & & & 65.68 \\
\hline & OL & & & & & & & 11.66 & & & & & 11.54 \\
\hline \multirow[t]{4}{*}{2014} & $\mathrm{C}$ & 4.47 & & & & & & 7.83 & & 7.60 & & & \\
\hline & SSF & 18.20 & N/A & N/A & N/A & N/A & N/A & 25.39 & N/A & 23.41 & N/A & N/A & N/A \\
\hline & SS & 42.68 & & & & & & 56.82 & & 55.49 & & & \\
\hline & OL & 34.65 & & & & & & 9.96 & & 13.50 & & & \\
\hline \multirow[t]{4}{*}{2015} & $\mathrm{C}$ & & & & & & & - & 8.16 & & 7.88 & & \\
\hline & SSF & NA & N/A & N/A & N/A & N/A & N/A & 31.80 & 12.94 & N/A & 3.63 & N/A & N/A \\
\hline & SS & & & & & & & 59.83 & 50.79 & & 37.95 & & \\
\hline & $\mathrm{OL}$ & & & & & & & 8.37 & 28.10 & & 50.54 & & \\
\hline
\end{tabular}

Note: N/A: Not available, C: Cloud, SSF: Secondary swamp forest, SS: Shrub swamp, Open land (OL)

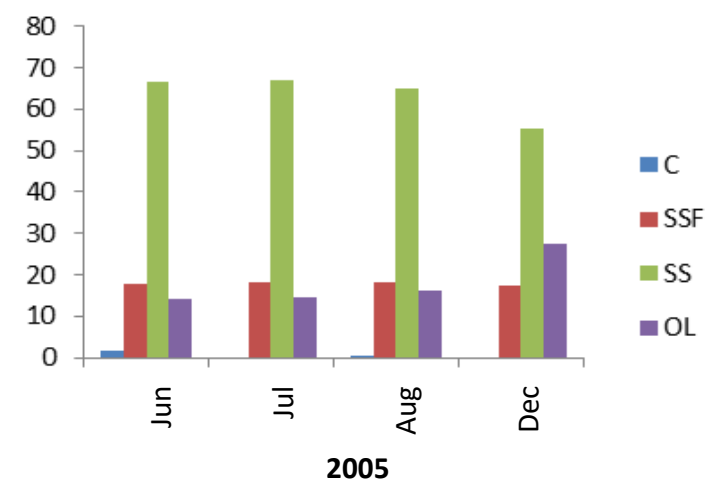

A

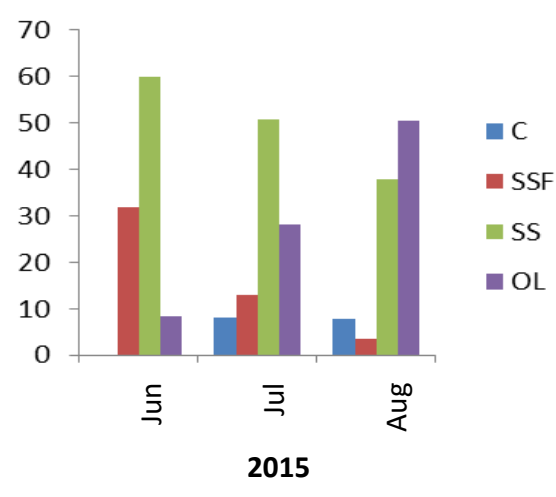

B

Figure 4. Land cover changes (ha) in 2005 (A) and 2015 (B) in block A Ex-Mega Rice Project

\section{Discussion}

This research area is administratively located in several villages in the District of Mantangai, namely Katunjung, SeiAhas, Katimpun, Kalumpang, Mantangai Hulu and Mantangai Tengah. The factors that cause land cover patterns in block A of ex-MRP are the use of land for farming, forest fires, and socio-economic factors. Those areas are inhabited by the Dayak Ngaju communities who use fire for the land preparation through controlled burning. The pattern of land cover or land use in the region is the result of natural and socio-economic factors as well as the use of fire by humans in space and time (Rawat and Kumar 2015). 


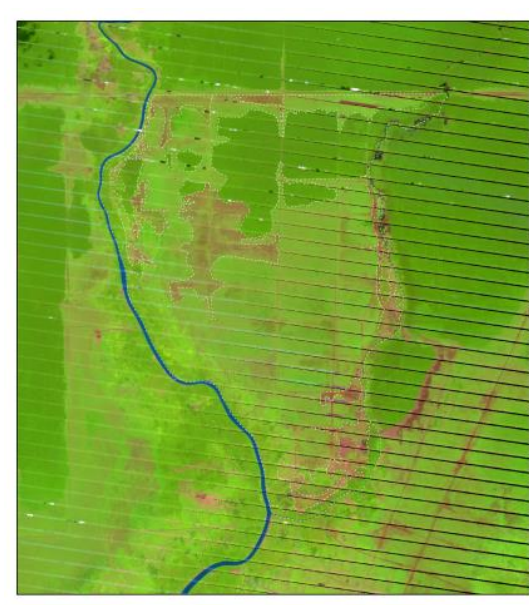

A

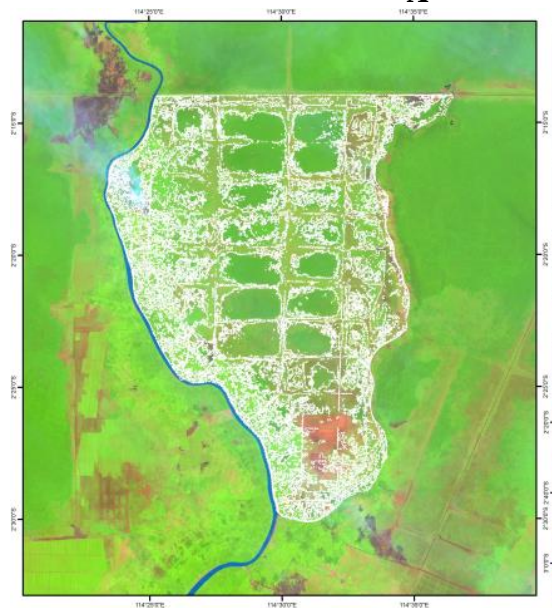

C

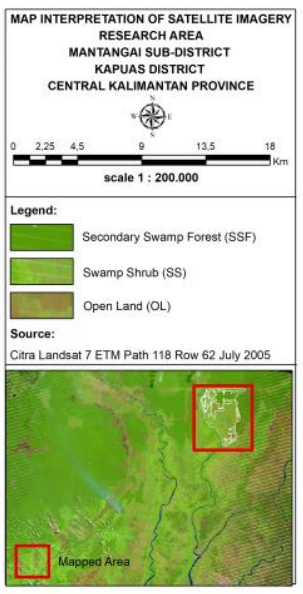

MAP INTERPRETATION OF SATELLTE MMAGERY

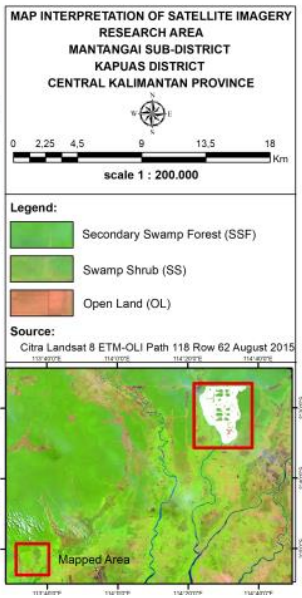

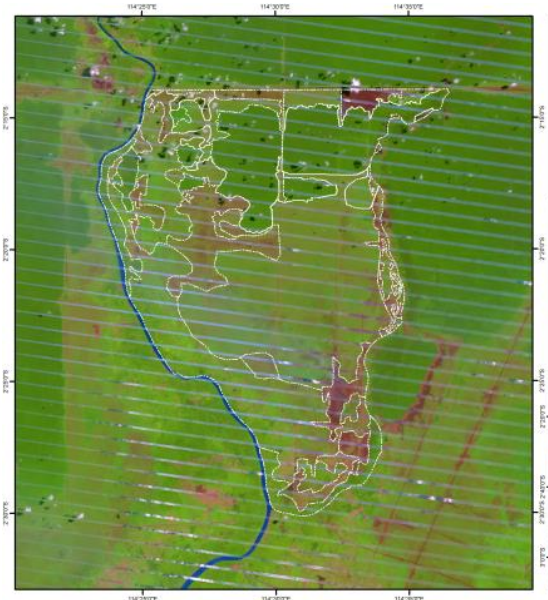

B

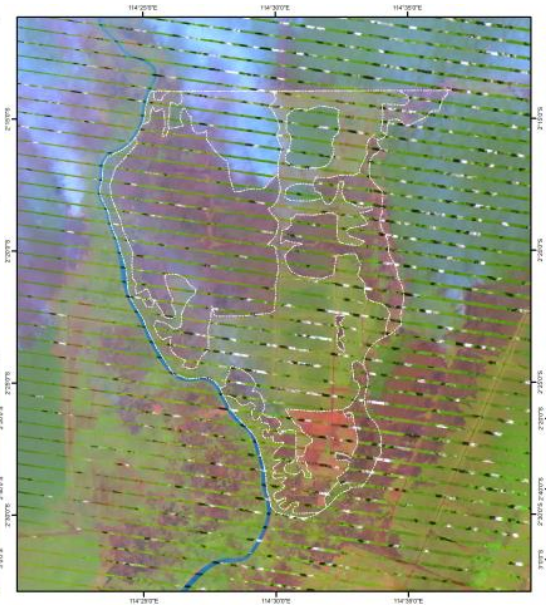

D
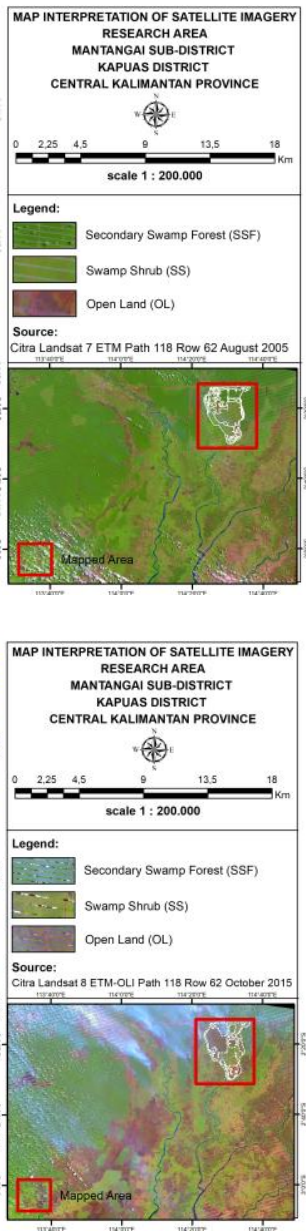

Figure 5. Satellite images interpretation maps due to the land cover changes in July 2005 (A), August 2005 (B), August 2015 (C), and October 2015 (D)

Land cover changes due to land clearing by fire occur during a certain month or season when the communities open the lands, starting with felling and logging which lead to changes in forest cover and surface. Felling and logging are followed by drying and finally burning which lead to the changes in land cover into an open area. The open land is then planted with rice called "padi gunung" (mountain rice). After having been harvested the land will be abandoned for several years (5-7 years) or it will be reused. Forest fires could also cause land cover changes with almost the same process as land preparation by the local peoples. Fire may cause forest fire and land cover change into open land, but it was not the same as it is applied for the rice planting. Land cover change due to fires during the dry season is a long process and may cause a change in land cover due to loss of vegetation (Saharjo and Munoz 2005, Saharjo 2011).

In 2005 the secondary swamp forest (SSF) was $17.77 \%$ in June, and then it turned into $18.06 \%$ in July, $18.17 \%$ in August and $17.51 \%$ in December. The SSF change each month in 2005 was not so significant, meaning that the public actually could not clear the forest that year. Meanwhile, the swamp shrub (SS) in June was $66.63 \%$ then it increased to be $67.18 \%$ in July, $64.93 \%$ in August and $55.25 \%$ in December. SS declined significantly in December, indicating that SS had been burned during August-November. Open Land (OL) was $14.06 \%$ in June, $14.76 \%$ in July, $16.27 \%$ in August and $27.54 \%$ in December, indicating that people had started to prepare the land for planting rice mountain "padi gogo".

In 2006 and 2007, the change was not so significant at the SSF, SS, and OL from July to August, implying that burning was not conducted. Unfortunately, the land cover changes in 2008, 2009, 2010 and 2011 could not be analyzed because most of the satellite images were covered by clouds.

In 2013, the land cover changes of SSF, SS, and OL from July to December were not significant, indicating that in the year 2013 the forest fires were very few as it could be seen by low the number of hotspots detected. In 2014, the land cover changes of SSF, SS, OL from July to September were not significant, presumably, the communities did not burn the land due to climatic conditions.

In 2015 the land cover of SSF significantly changed; in July it was $31.80 \%$, in September $12.94 \%$ and in October 
only $3.63 \%$. SS land cover also decreased significantly, from $59.83 \%$ in July to $50.79 \%$ in September and it reached the lowest point in October that was $37.95 \%$. As a consequence, OL cover increased significantly, from $8.37 \%$ in July to $28.10 \%$ in September, and it reached the lowest point in October that was 50.54\%. In 2015, fire occurred severely in the research area because it was also worsened by El-Nino which made it difficult to manage especially in the peat area.

Land cover changes from 2005 to 2015 in Mantangai Kapuas, Central Kalimantan Province were mainly exacerbated by climatic conditions. The fire that acted as an actor for the land cover change usually happened at the end of the dry season or the beginning of the rainy season as seen clearly through database of land cover change from satellite images. Research conducted by Ngaji (2016) shows that the rainy season affects land cover changes due to the availability of water, and climate is one of the supporting factors of land cover change in a region (Sylla et al. 2012).

Land cover changes that occurred in the study area in 2015 were not caused by the local peoples who opened the land to be used as fields, as they would not open deep peatland in the protected forest because the result would not be good. If the community conducted land clearing at deep peat at the protected forest for rice planting, then 3 months after planting the rice would die, this fact taken from their experience before.

Land cover types in the area of block A of ex-MRP consisted of secondary swamp forest (SSF), swamp shrub (SS) and Open Land (OL). Land cover changes which occurred in block A of ex-MRP were from secondary swamp forest into swamps shrub and at open land from secondary swamp forest into fields. Land cover changes usually occurred in late September because people started to burn to prepare the land. Land cover changes that occurred in blocks A Ex-MRP which was at protected area dominated by peat was not caused by land preparation using fire by DayakNgaju communities.

The results of research have shown that the changes in land cover in Block-A ex-MRP where Dayak Ngaju communities live were not significant. Actually, the local peoples as it found in many places usually would utilize the protected area that is very close to their land and accessible, but Dayak Ngaju communities did not do it, so the protected area still existed. This is the way how the local peoples implement their knowledge and experience not to burn the land that does not belong to them and the burning of this land will not benefit them and the environment.

This study also found an important result that the significant factors causing the forest and land fires near the Dayak Ngaju area were land rights conflicts. Another community burned the land to avoid the seizure of land by the state. Indonesian Law No. 5 the year 1960 regarding Basic Regulation of Agrarian Principles in Article 27 states that the property will fall into the state for reasons: (i) for revocation of rights under Article 18; (ii) for submission voluntarily by their owners; (iii) because it is abandoned; (iv) due to the provisions of article 21 paragraph 3 and 26 paragraph 2 (RI 1960). Land left for years will be grown by bushes, looking like abandoned land.

\section{REFERENCES}

Esmaila M, Masriab A, Negm A. 2016. Monitoring Land Use/Land Cover Changes Around Damietta Promontory, Egypt, Using RS/GIS. Proceeding Engineering 154: 936-942.

Goldammer JG. 1993. Fire Management. In: Pancel L. (ed.). Tropical forestry handbook. Vol. 2: 1221-1267.

Greenpeace. 2015. Indonesia terbakar: dalam kepungan api "Krisis kebakaran Indonesia adalah ujian bagi komitmen korporasi terhadap perlindungan hutan". [Indonesian]

Hadiwijoyo E, Saharjo BH, Putra EI. 2017. Local wisdom of DayakNgaju in Central Kalimantan on land preparation by using fire. Jurnal Silvikultur Tropika 8 (1): 1-8.

Haque MI, Basak R. 2017. Land cover change detection using GIS and remote sensing techniques: A spatio-temporal study on TanguarHaor, Sunamganj, Bangladesh. The Egyptian Journal of Remote Sensing and Space Sciences 20: 251-263.

Harper AR, Doerr SH, Santin C, Froyd CA, Sinnadurai P. 2017. Prescribed fire and its impacts on ecosystem services in the UK.

Koshurnikova N, Verkhovets S, Antaoshkina O, Trofimova N, Zlenkoe L, Zhuikov A. 2015. Assessment of Central Siberia forest ecosystems sustainability to forest fires: academic research outcomes. Procedia Soc Behav Sci 214: 1008-1018.

Lillesand TM, Kiefer RW. 2000. Remote Sensing and Image Interpretation. 4th ed., Wiley \& Sons, New York

Ngaji AUK. 2016. Pengaruh Perubahan Tutupan Lahan Terhadap Kondisi Hidrologi Kawasan Daerah Aliran Sungai Talau. J Partner 1: 51-55.

Nye PH and DJ Greenland. 1960. The soil under shifting cultivation. Tech. Comm. 51, Commonwealth Bureau of Soils, UK.

Rawat JS, Kumar M. 2015. Monitoring land use/cover change using remote sensing and is techniques: A case study of Hawalbagh block, district Almora, Uttarakhand, India. Egypt J Rem Sens Space Sci: 7784.

RI [Republik Indonesia]. 1960. Undang-undang Republik Indonesia No. 5 Tahun 1960 Tentang Peraturan Dasar Pokok-pokok Agraria. [Indonesian]

Saharjo BH. 1995. The changes in soil chemical properties following burning in a shifting cultivation area in South Sumatra. Wallaceana 75: $23-26$

Saharjo BH, Munoz CP. 2005. Controlled burning in peatlands owned by small farmers: a case study in land preparation. J Wetlands Ecol Manag 13: 105-110.

Saharjo BH. 2011. The impact of surface fires on peatland in the land preparation area belong to the community. Global Environ Res 15(1): $39-44$

Saharjo BH. 2016. Pengendalian Kebakaran Hutan dan atau Lahan Indonesia. IPB press, Bogor. [Indonesian]

Saharjo BH, Syaufina L, Nurhayati AD, Putra EI, Wardana. 2017. Pemanfaatan Lahan Gambut dan Emisi Gas Rumah Kaca. IPB Press, Bogor. [Indonesian]

Schroeder W. 2016. Active fire detection using Landsat-8/OLI data. Remote Sens Environ 185: 210-220.

Sylla L. 2012. A GIS technology and method to assess environmental problems from land use/cover changes: Conakry, Coyah, and Dubreka region case study. Egyptian J Rem Sens Space Sci 15: 31-38.

Syaufina L. 2008. Kebakaran Hutan dan Lahan di Indonesia. Bayumedia Publishing, Malang. [Indonesian] 